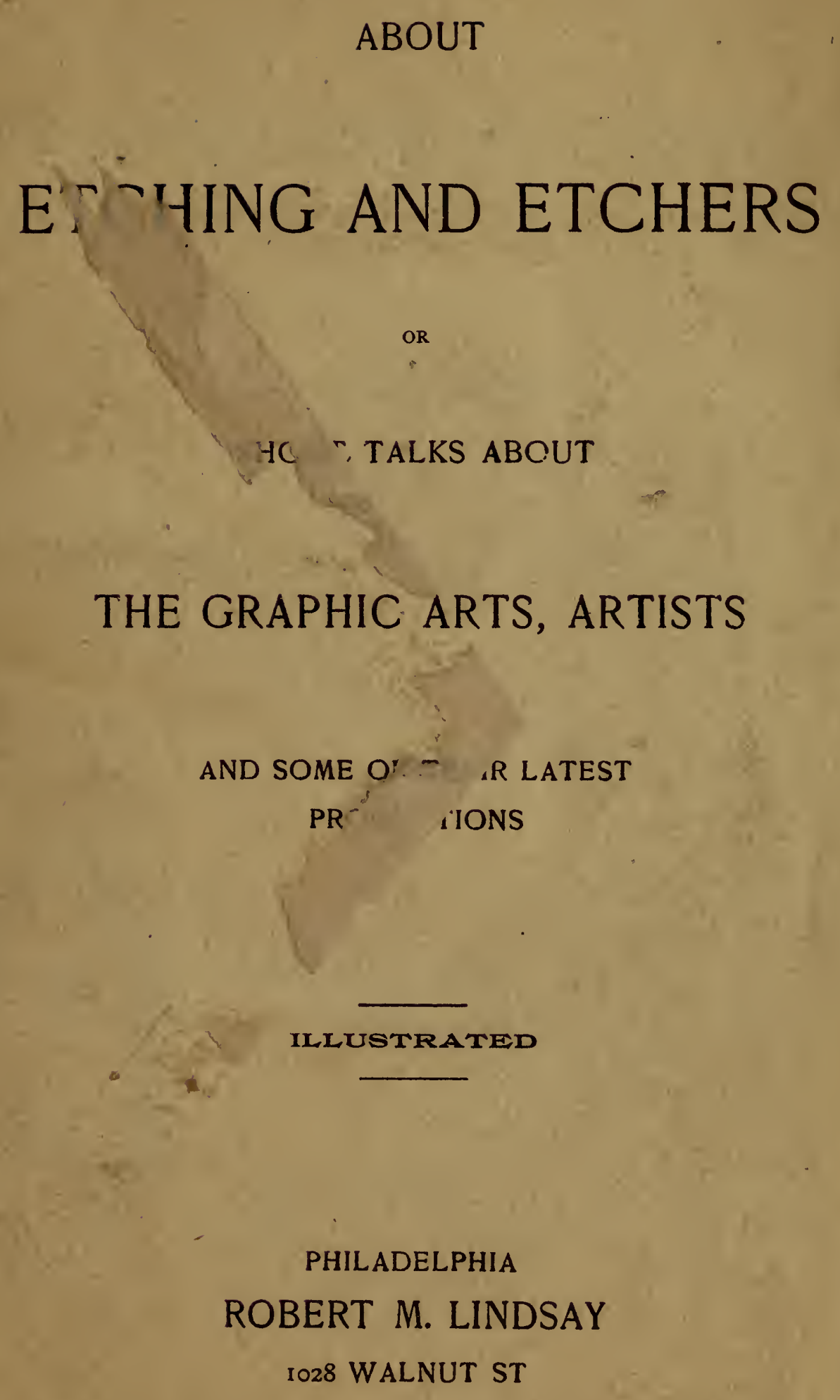



ABOUT

\section{ETCHING AND ETCHERS}

OR

SHORT TALKS ABOUT

THE GRAPHIC ARTS, ARTISTS

AND SOME OF THEIR LATEST

PRODUCTIONS

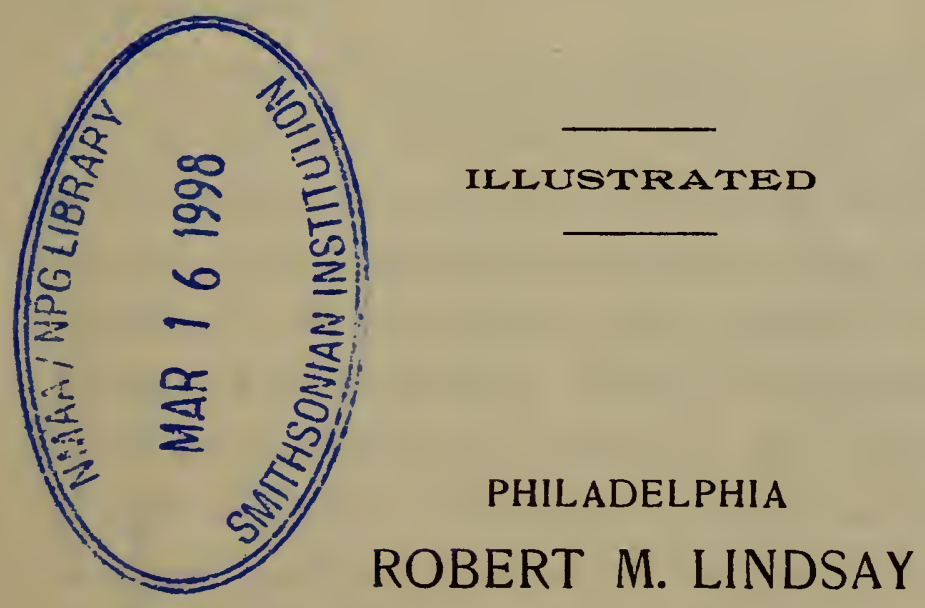

IO28 WALNUT ST 


$$
\begin{aligned}
& \text {. - }
\end{aligned}
$$

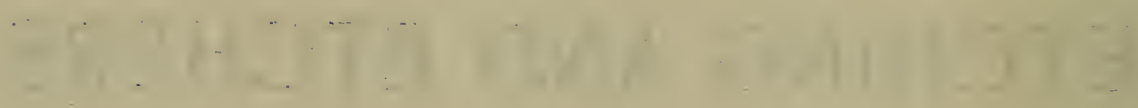

$$
\begin{aligned}
& +\quad+
\end{aligned}
$$

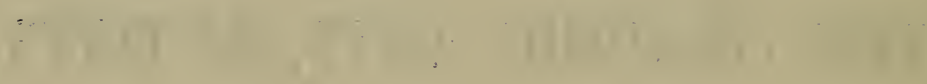

$$
\begin{aligned}
& +\frac{1}{2+1}+\infty
\end{aligned}
$$

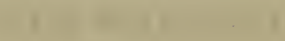

$$
\begin{aligned}
& \text { 1. : : } \\
& 1+2-1 \\
& 1+1 \quad \div
\end{aligned}
$$




\section{ABOUT ETCHING AND ETCHERS.}

T INES are the best means of expression in art, and L the best instruments are those which will most delicately, truthfully and freely form them with the least possible hindrance.

In none of the graphic arts are means employed by which lines can be formed equal to the etched line in any of its many superior qualities. No pen can approach it in fineness, delicacy, or homogeneity, nor can the pen bc moved in more than one direction without risk of blot and blur. The etching needle can be moved with equal facility in any direction. Pencil and crayon are crude instruments in comparison.

Though not a new art, etching has only lately ceased to be "an art for artists only." From the time of the first great etcher, Rembrandt, until about the middle of this century it was practically unknown to the public, and not supposed to be of practical utility, except for small, sketchy plates and for preliminary etching for engravers. Many of these studies have found their way into modern public and private collections, where they are esteemed as the original works of the great old masters, and are of as much artistic value as their paintings. 
All this has materially changed in our day, and the most ambitious works by our greatest artists are now done in etching.

Mr. William Hole, of the Royal Scottish Academy, whose attention has heretofore been devoted to small etchings and great paintings, has just reversed the order and produced a really great etching- "A Canterbury Pilgrimage." Many great painters have turned their attention to etching and have become greater artists in etching than they ever were in painting.

Mr. Hole's paintings have been assigned places of honor in exhibitions of such institutions as the London Royal Academy. The present subject would no doubt have been more successful in painting than anything he had previously executed, but his love for Chaucer and the motive of this picture, which had been in his mind for many years, prompted the decision in favor of etching as best adapted for the subject.

This plate is in many respects the most remarkable ever produced. We know of no ambitious original etching by a great painter-etcher which can be called so successful in the line of figure subjects. Mr. P. G. Hamerton (editor of the "Portfolio"), perhaps the most competent authority of our day, speaks thus of Mr. Hole's etchings:

"The technical quality of Mr. Hole's work is part of its vitality. It is completely without false pretension, and has none of the heaviness attendant upon mere industry. It is thoroughly sound and expressive work in a simple kind, and a just critic could find nothing to say against it. An unjust one might compare it with etching of greater technical resources, but that would be comparing it with another art." 


\section{A CANTERBURY PILGRIMAGE.}

Oblong, $16 \times 36$ in.

An Original Etching by William Hole, R.S.A.

Upon Japanese paper, with remarque (portrait of the artist). 200 printed $\$ 4800$ Upon Japanese paper, signed. 100 printed ........ . . 3600 Upon India paper, before letters. 100 printed . . . . . . . 2400 Prints ................... 1200 



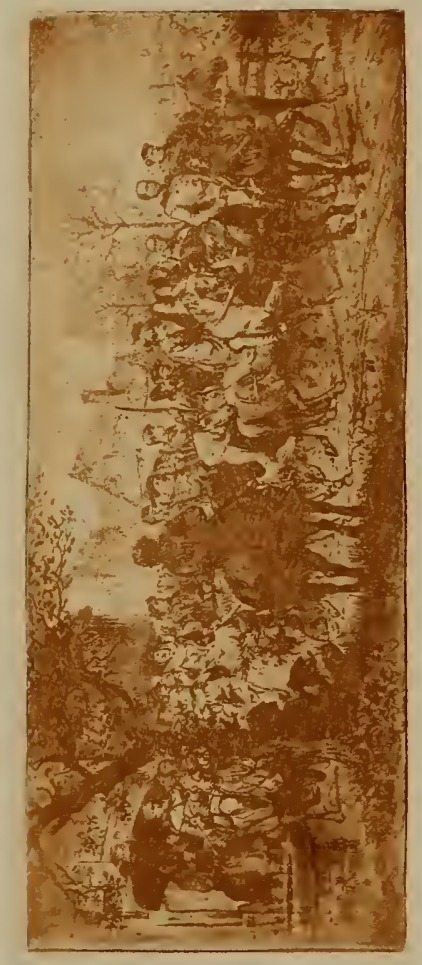



In speaking of the Canterbury Pilgrimage, Mr. Hamerton says (see "Portfolio," October, I888):

"Its principal merit is the clear discrimination of character without any tendency to caricature. Every one of the figures and faces is marked by strong individuality. They are all firmly drawn, and the female faces are not wanting in delicacy. The attitudes are cheerful and lively, like those of people setting forth on an agreeable expedition. The animals are rather heavy and deficient in charm, but they are felt to be secondary. Indeed, the horses are purposely made rather small size to give importance to the riders.

"On the whole the work is important and interesting, and likely to add to the artist's reputation. The technical quality is simple and sound throughout."

Following is an extract from the artist's remarks about his own work:

"You ask what first made me think of undertaking to etch my large plate of 'The Canterbury Pilgrims;' a question most difficult to answer, for who can trace the first germ. thought of a work of art, or define its motive in language?

"It has, in fact, been long on my mind to attempt the illustration of this subject, as it seems exceptionally suitable for the purpose, both from an artistic and an historic point of view, but which has been depicted, as far as I am aware, by two artists only; each great in his own way, but unsuited I think by the very individual and personal character of their art from assimilating the ideas of another author, or following the lines so clearly and incisively laid down by old Chaucer, whose word-painting, if ever man's did so, literally holds the mirror up to nature. 
"Stothard was essentially a colorist, but his characters are lacking in individuality. Blake, on the other hand, erred in the opposite direction; his sombre power of imagination urging his delineation of character to the verge of caricature, if indeed he did not overstep the boundary.

"I have therefore ventured to put forth a third illustration of the celebrated prologue, as the space seemed open for it without challenging comparisons, on their own lines, with the works of greater men.

"Need I remind you of Chaucer's opening description of the glad April morning in Old England, 500 years ago?

- Whan Zephirus eek with his swete breeth

Inspired hath in every holte and heethe

The tendre croppes,

And small fowles maken melodie,

Thanne longen folk to gon on pilgrimage.'

As we still with similar impulse long for an excursion in the country.

"The Pilgrimage, as is evident from the context, has but a slight flavor of religion about it, the word being for the most part a very transparent cloak for 'a holiday,' in which again five hundred years has worked little change in our ways.

"So nine and twenty in a company of all sorts and conditions of men and women 'by aventure i-falle in felawschipe,' at the sign of the Tabard Inn, Southwark, with intent to ride forth on the morrow to the shrine of St. Thomas a'Becket at Canterbury. With them will fare stout Harry Bailly, the host, glad to escape for the nonce from the tongue of 
his shrewish wife, and exercise a little brief authority as self-constituted leader of the band and master of ceremonies.

"They all gladly assent to his proposal that each in turn shall tell some story to enliven the journey; and here follows The Canterbury Tales.

"I have, as you see, represented our pilgrims sallying forth from the court-yard of the old Inn, then standing on the outskirts of Southwark; their road leading them along the south bank of the Thames.

"Foremost rides the knight, one of the few who are thoroughly in earnest in looking upon the pilgrimage as a religious duty, accompanied by the monk-that worldly man -and followed by the aristocracy of the company, the representatives of society, science and fashionable religion. After them ride commerce and middle class respectability, and behind them again a contingent, whose mirth tends to rowdyism, and whose subsequent contribution of tales tends not to edification. Then come sundry quiet, thoughtful men, content to take an unassuming place in the ranks, while the rear is brought up by the observant poet himself and the Reeve who ever rode hindermost of the route. The host, having marshalled his troop, stands aside to see that all have passed, whilst an old blind beggar petitions for a dole from those whose offerings are reserved for another sepulchre of bones more dead than his. Each head is a portrait of some individual whose character, so far as it is borne out by physiognomy and expression, corresponds with that of an actor in Chaucer's drama.

"By gleaning in highways and byways, public men and obscure men have wittingly and unwittingly been focussed in the camera." 
The name of H. R. Robertson, R.A., has been before the art public many years through his writings which have from time to time appeared in the art journals, and his books which have aided many a young artist to success. His handbook on etching is perhaps the best elementary work on the subject.

Above all his literary work and his paintings, his etchings have a peculiar charm which is unique and characteristic of his work alone.

How like a real painter's etching is his latest work (here represented), etched with the true love which only the painter can, as a rule, possess for his own subject! To say that it is "perfect" would be to praise without reserve, but to say that it is a most beautiful picture of its kind in both composition and execution-the work of a consummate master-is modest praise.

It is a cloudy English atmosphere, a sad moving-day for the father and mother whom the young folks are towing away from their good old home.

He finds comfort, however, in quiet reflection, while she fondly nurses a grandchild; and who can measure the peaceful joy of a grandmother, even though surrounded by apparent sadness, if she can fondle a favorite grandchild? This is not only "a picture with a story," but one with a story well told.

Another original etching is "On the Neshaminy," by Peter Moran. As is well known, there are several American artists with the name Moran, of whom the best known are perhaps Peter and his brother Thomas, the marine artist.

Two new etchings by the latter, called "The Gate of 


\section{LEAVING THE OLD HOMESTEAD.}

Oblong, $17 \times 27^{1 / 2}$ in.

An Original Etching by H. R. Robertson, R.A.

Upon Japanese paper, with remarque, signed. Limited to $250 \mathrm{im}$ pressions ............. \$18 00

Prints ....................... 600 


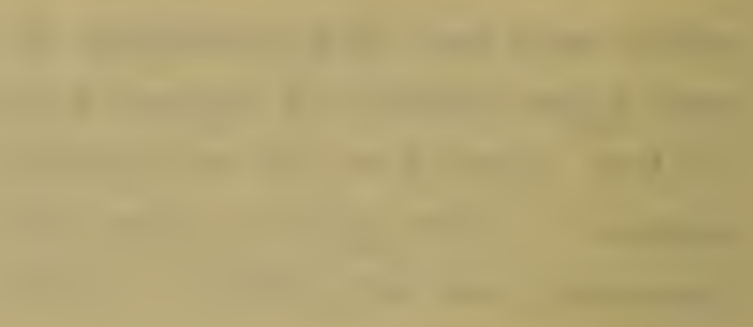

$\sqrt{2}+x^{2}$
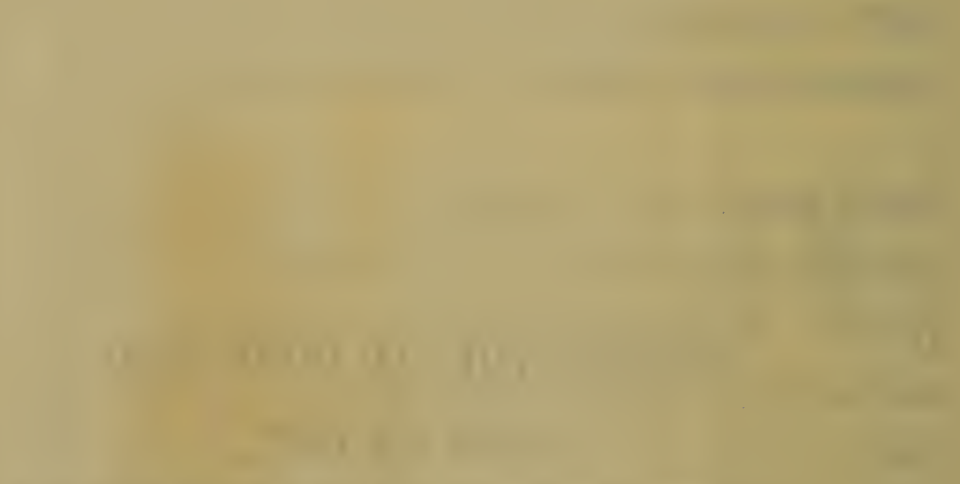

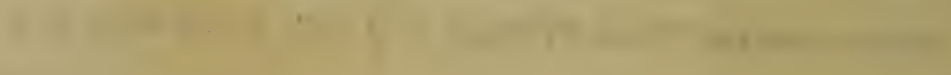

-

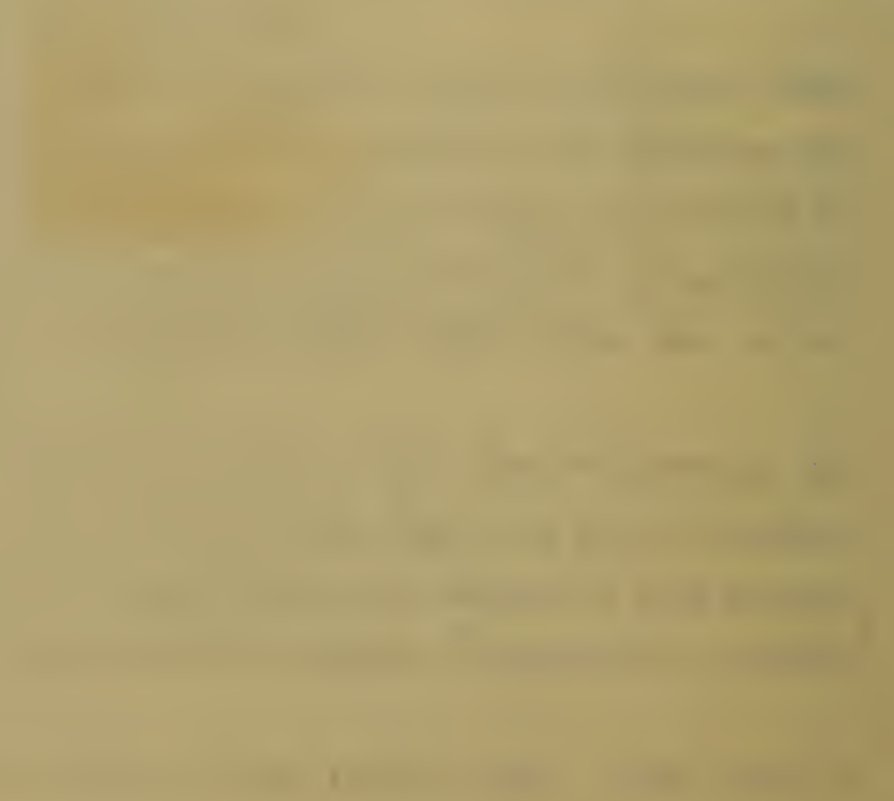




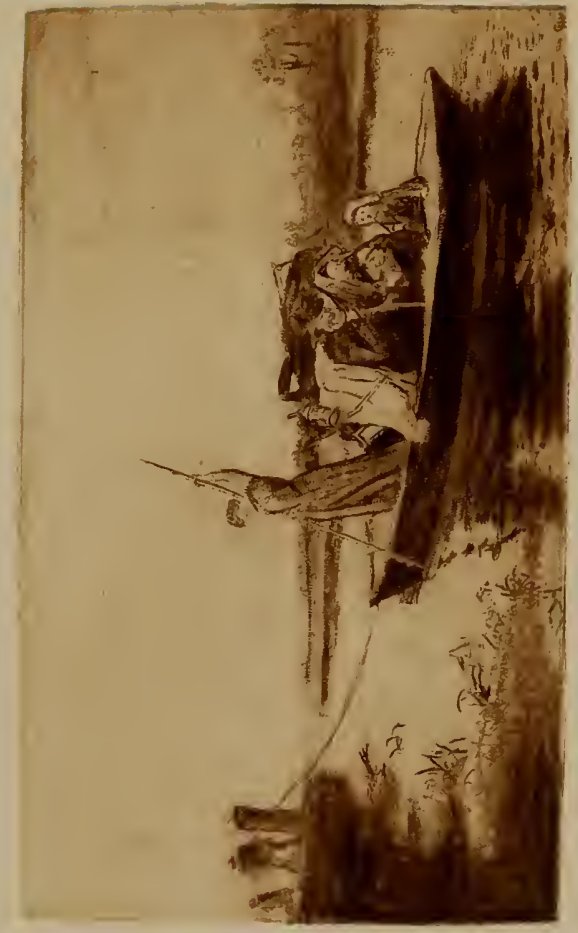





\section{ON THE NESHAMINY.}

Oblong, $17 \times 24$ in.

An Original, Etching by Peter Moran.

Upon vellum, with remarque, signed. 25 printed . . . . \$ \$50 o0 Upon Japanese paper, with remarque, signed. 75 printed . . . . 35 co Upon Japanese paper, signed. 150 printed . . . . . . . 2000 No prints of this etching will be issued. The plate has been destroyed. 


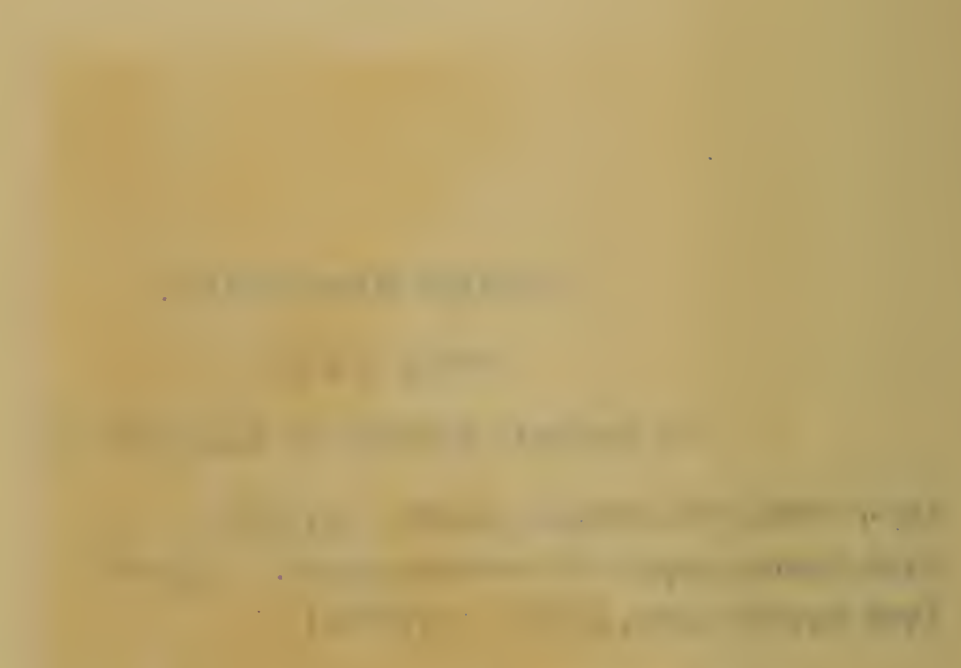

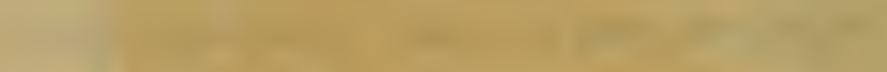




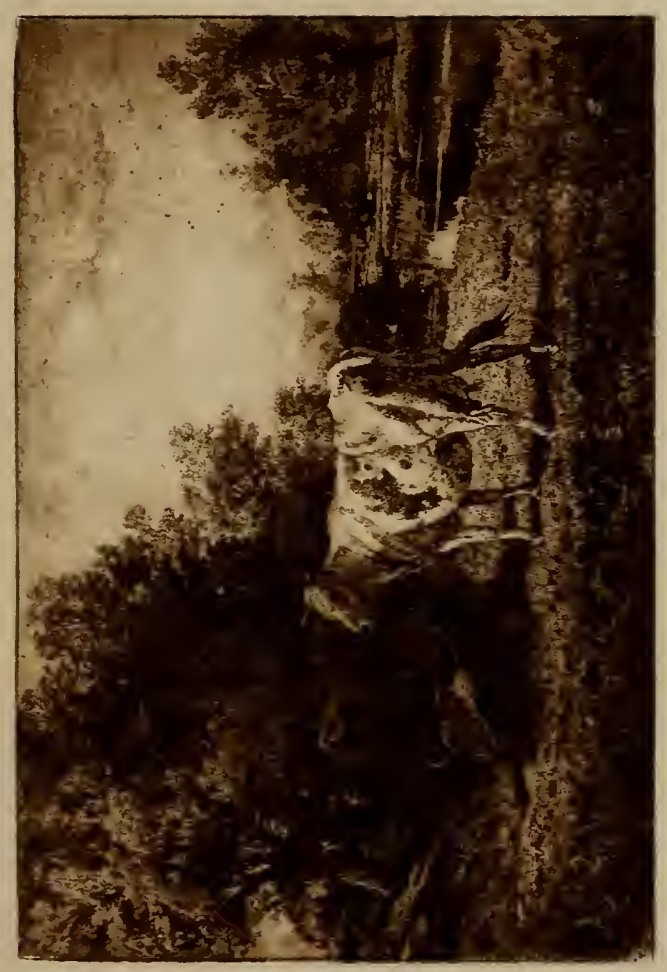



Venice" and "Mount of the Holy Cross," are perhaps his best work. They are very much like Turner in general effect.

"On the Neshaminy" is pronounced to be Peter Moran's best work. No American etcher has ever learned the full value of a well drawn, decidedly etched line better than this artist, and he has displayed this power nowhere better than in the present plate.

It would be difficult to find another plate with equally fine effect, produced by simple means which being well directed are so successful.

This method of etching, in Mr. Moran's hands, seems most peculiarly adapted to his line of subjects, which are mostly pastoral.

Mr. J. Henry Hill is a well-known etcher whose plates have been numerous, but "The Return to Port" is decidedly his best; and although not a painter-etching, strictly speaking, it has many of the fine qualities which are characteristic of the greatest original work. Mr. Hill is a well-known painter and has etched many original plates, which accounts somewhat for his painter-like interpretation of this splendid picture after Eugene Isabey. In the catalogue of all existing marine pictures it would be difficult to find another with such spirit and dash, and at the same time so harmoniously effective as an etching.

Another original etching of the season is by Edward Barclay, the etcher of "The Old Steps at Capri," which has been popular, and is most rare in proof state. It is entitled "The Olive Harvest," and represents a charming scene of olive gathering on a bright, sunny mountain slope. Following are extracts from the artist's own remarks: 
"The scene depicted is amongst mountains named the Jurjura, a branch of the Atlas range in the province of Algiers. I first visited this region in 1873 , again in 1877 , and in 1880 , in company with a friend, I camped for several months amongst the tribes. The result of these journeys was numerous pictures, and a little book entitled 'Mountain Life in Algeria,' published by Messrs. Kegan, Paul, Trench \& Co., I882. I herein described the olive harvest as follows:

'When olives are plentiful the gathering lasts for several months, beginning in October and not ending till February, and it is a charmingly picturesque sight. Men standing round a tree beat down the fruit with long wands, then they climb up to beat and shake the branches till all the olives have fallen. 'As the shaking of an olive tree, two or three berries in the top of the uppermost bough, four or five in the outmost branches thereof,' is a biblical simile for a small remnant. Upon an early Greek vase in the British Museum is depicted an olive tree being stripped of its fruit in the manner described. Meanwhile the women are busy, working side by side, picking up the fallen fruit and putting it into baskets which are emptied upon cloths spread on the ground. At close of day the heaped berries are poured into sacks, and carried up to the villages on mules. . . . .

"The simple dress of the mountaineers is the same as that of ancient Greece. They are clothed in a single piece of home woven drapery, attached beneath the shoulders with broaches, and gathered round the waist with a girdle. The round broaches on the heads of the two women are a sign of maternity. These 'round tires' are made of 


\section{THE RETURN TO POR'T.}

Oblong, $223 / 4 \times 273 / 4$ in.

Etched by J. Henry Hill, from the Painting by Isabey.

Upon Whatman's hand made paper, with two remarques, signed. Ioo printed .............. \$50 o0

Upon Whatman's paper, signed. Ioo printed . . . . . . 15 o0

No prints of this plate will be issued. 



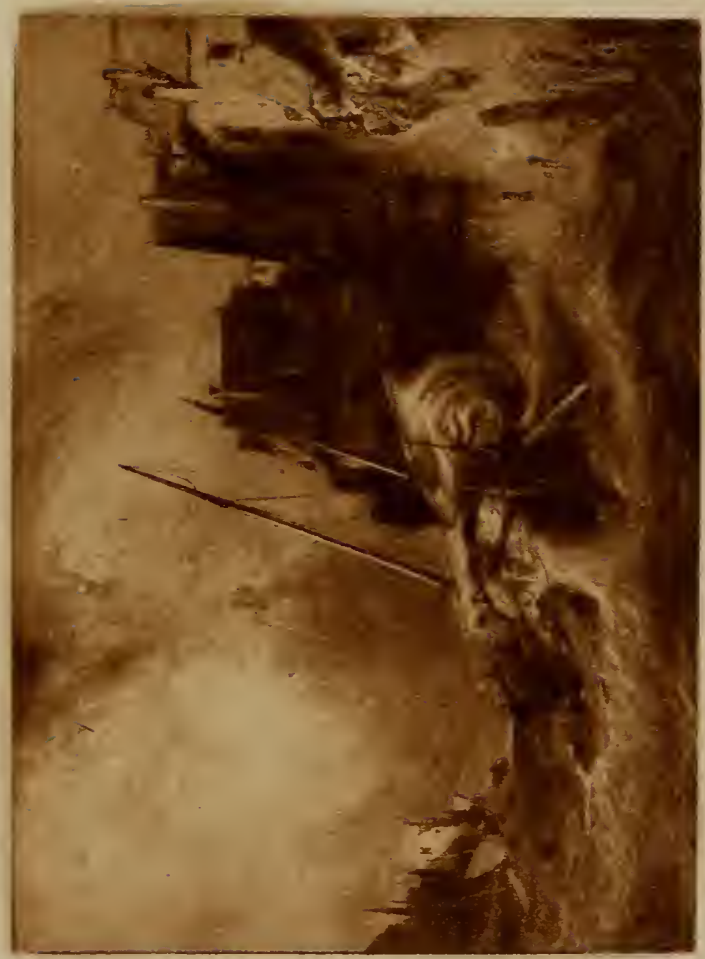





\section{THE OLIVE HARVEST.}

Oblong, $181 / 2 \times 22$ in.

Etched by Edgar Barclay, from his own Painting.

(Grosvenor Gallery, 1883.)

Upon Japanese paper, with remarque, signed. 200 printed . . . \$30 00

Prints .................. 6 o . . . 



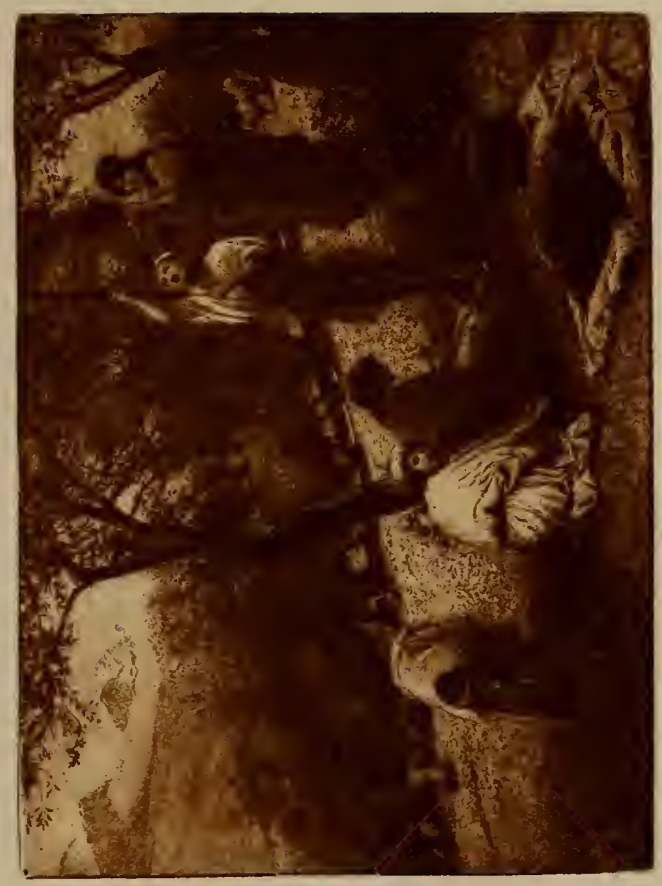



silver with embossed pieces of coral. After giving birth to a daughter the ornament is worn between the breasts, after the birth of a son it is worn above the forehead."

Among the names of the modern French school of etchers there are perhaps none greater than Charles Courtry, who might indeed be ranked among the fathers of the modern revival. His etchings date almost as far back as the earliest works of Leopold Flameng, and have had a strong influence in developing this art in France. He received the Medal of Honor, Paris Salon 1887, and was elected to the Jury of the Salon, 1888. "Entre deux feux" is his last important work, and, like most plates by the French masters of etching, it is after a great picture.

French etchers excel in elegant technical qualities, which they rather choose to devote to the interpretation of great existing pictures than to the creation of new ones; this latter art they leave for the most part to their painters who etch very little.

How admirably the manner of etching in this picture is adapted to the light and delicate style of the Spanish artist Jiminez!

The etching is full of color and sparkle. The Spanish court-yard glows with lights, and no undue shadows mar the effect. The two groups of figures, though differently occupied, are equally absorbed, and equally unmindful of the other's proximity. Notice how the two young ladies in the principal group have succeeded in puzzling the young cavalier almost to distraction by their tantalizing conversation, emphasized by their simulated industry in embroidering.

"La Priere," after Charles Sprague Pearce, by R. de 
los Rios, is another new and fine specimen of this same school of etching. The texture of the skin, with the delicate features of the face and hands, are here delightfully rendered; the remaining parts being rich and bold, emphasizing the pathetically interesting face, and forming a striking contrast. It is a most appealing little picture of "a real prayer." De los Rios received a medal, Paris Salon I 888. The name of Charles Sprague Pearce is now one of the greatest among living American artists.

P. Teyssonnieres' name will be found among the original etchers who contributed to the annual publications of Cadart, L'Art and the French Etcher's Society-the mediums which have contributed largely toward putting France in the front rank for etching. His etching of "Mary, Queen of Scots," is elaborate and faithfully executed throughout. It is a good interpretation of the beautiful little portrait in St. James' Palace, taken from life when she was young and attractive.

In connection with portraits it may be interesting to note that the art of mezzotinting is especially adapted for head subjects, and although few good mezzotinters have appeared in our day, three which have been lately published (Isabel, Cynthia and Marcia) seriously rival almost anything done by the old masters of the art, whose works were the glory of the engraver's art in England a hundred years ago.

Last but not least in the catalogue of new etchings is Mr. John Fullwood's jolly subject "When the Reaper's work is done." This is an original etching based upon a scene at Twickenham Ferry, near the artist's own home. Few etchers can compose and etch so well at the same 


\section{"ENTRE DEUX FEUX."}

Etched by Ch. Courtry, from the Painting by L. Jiminez. Upon parchment, with remarque, signed. roo printed ..... . \$36 00 Upon Japanese paper, with remarque, signed. roo printed . . . . 2400 India proofs . . . . . . . . . . . . . . . . 1200 Prints.................... 600 


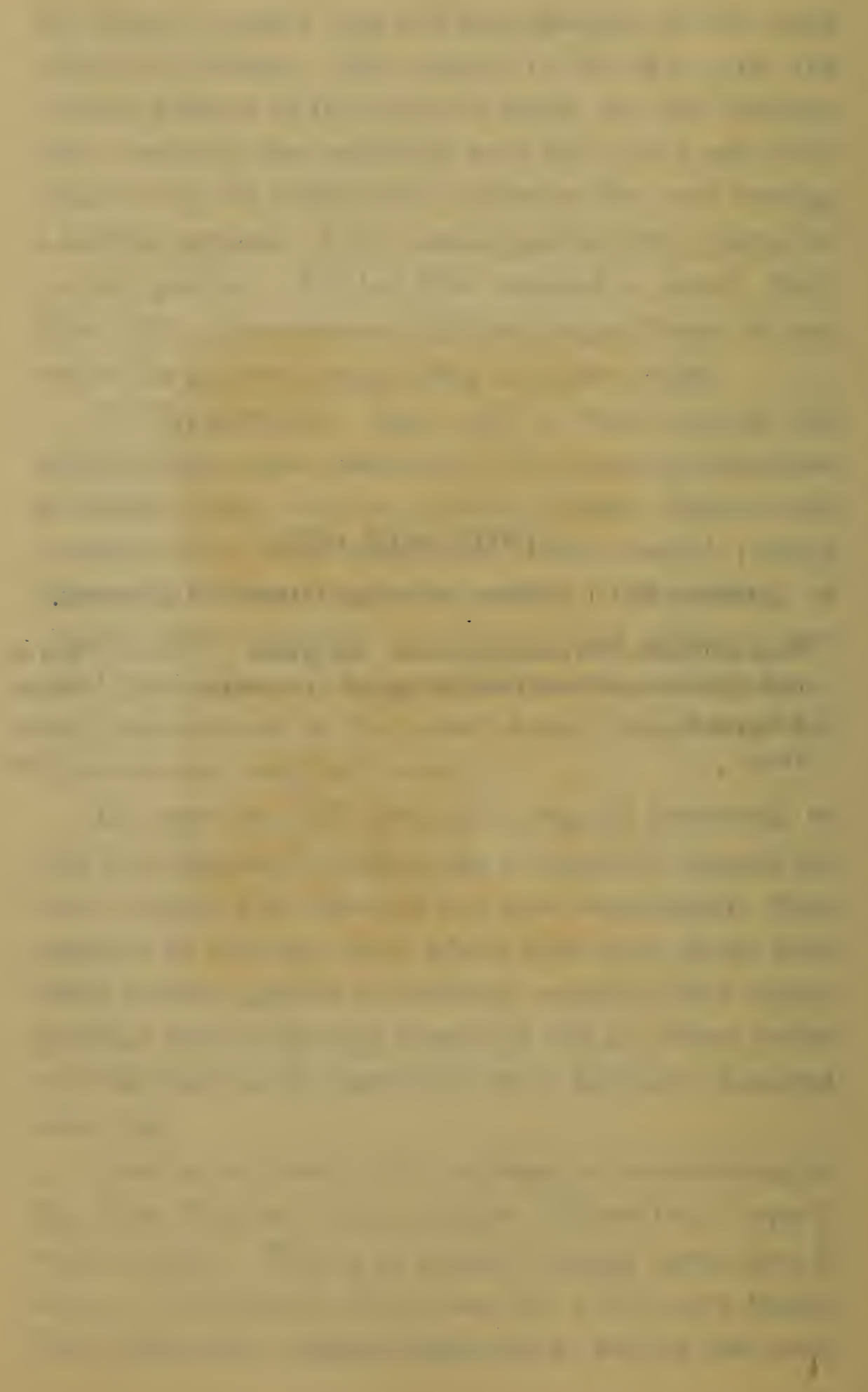




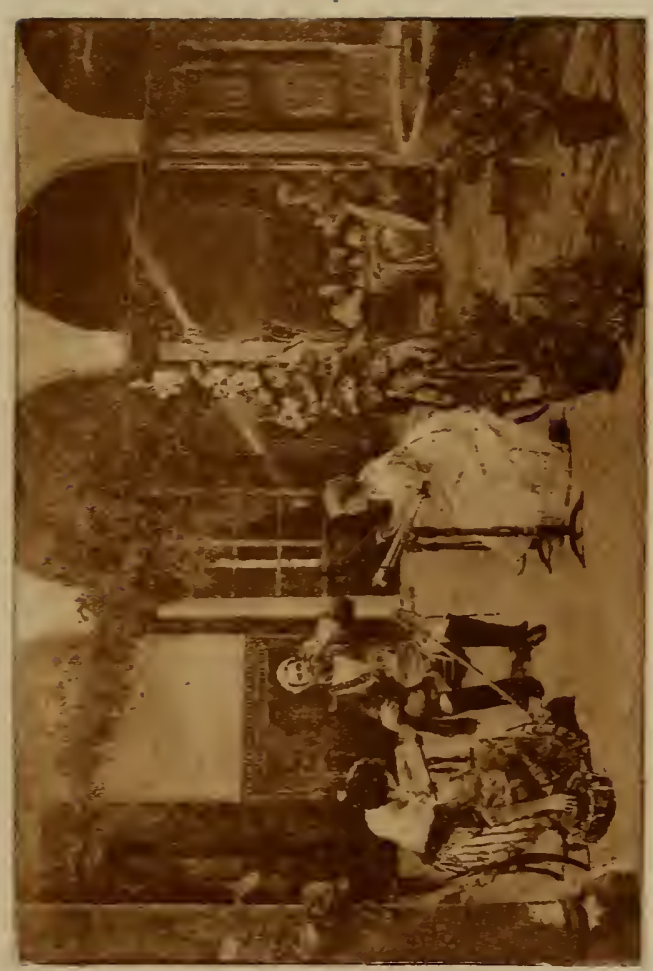





\section{THE PRAYER.}

Upright, I2 $x$ I6 in.

Etched by R. De los Rios, from the Painting by Charles Sprague PeARCE.

Upon vellum, with remarque, signed by both artists. I00 printed. . \$15 $\$ 0$ Upon Japanese paper, with remarque, signed by both artists. 100 printed .................... I0 00

Upon Japanese paper, signed by the etcher. Ioo printed .... 500 



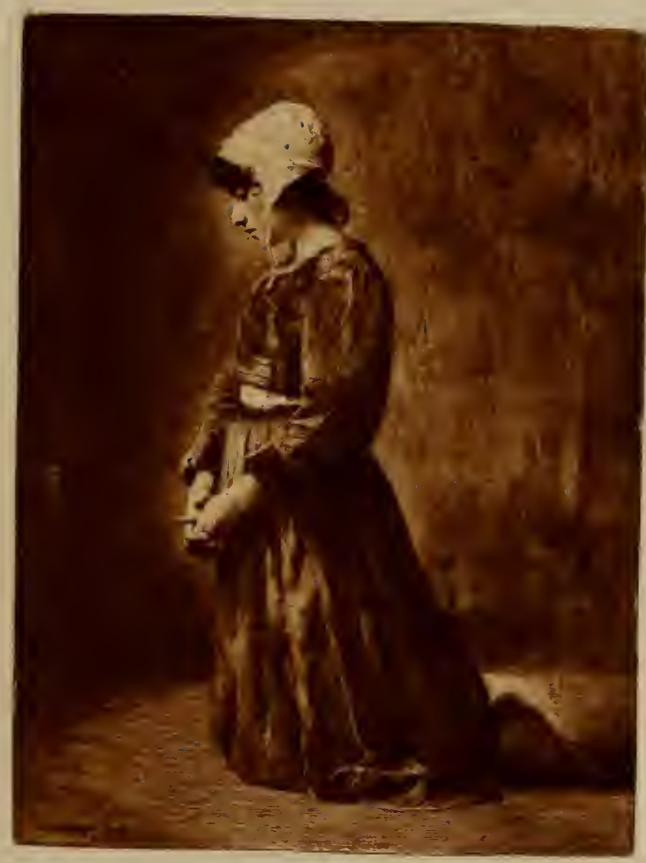



WHEN THE REAPER'S WORK IS DONE. (Twickenham Ferry.) Oblong, I9 $\times 3^{\mathrm{I}}$ in.

An Original Etching by John Fuliwood.

Upon parchment, with remarque, signed. Ioo printed . . . . \$48 00 Upon Japanese paper, with remarque, signed, Ioo printed ... 3600 

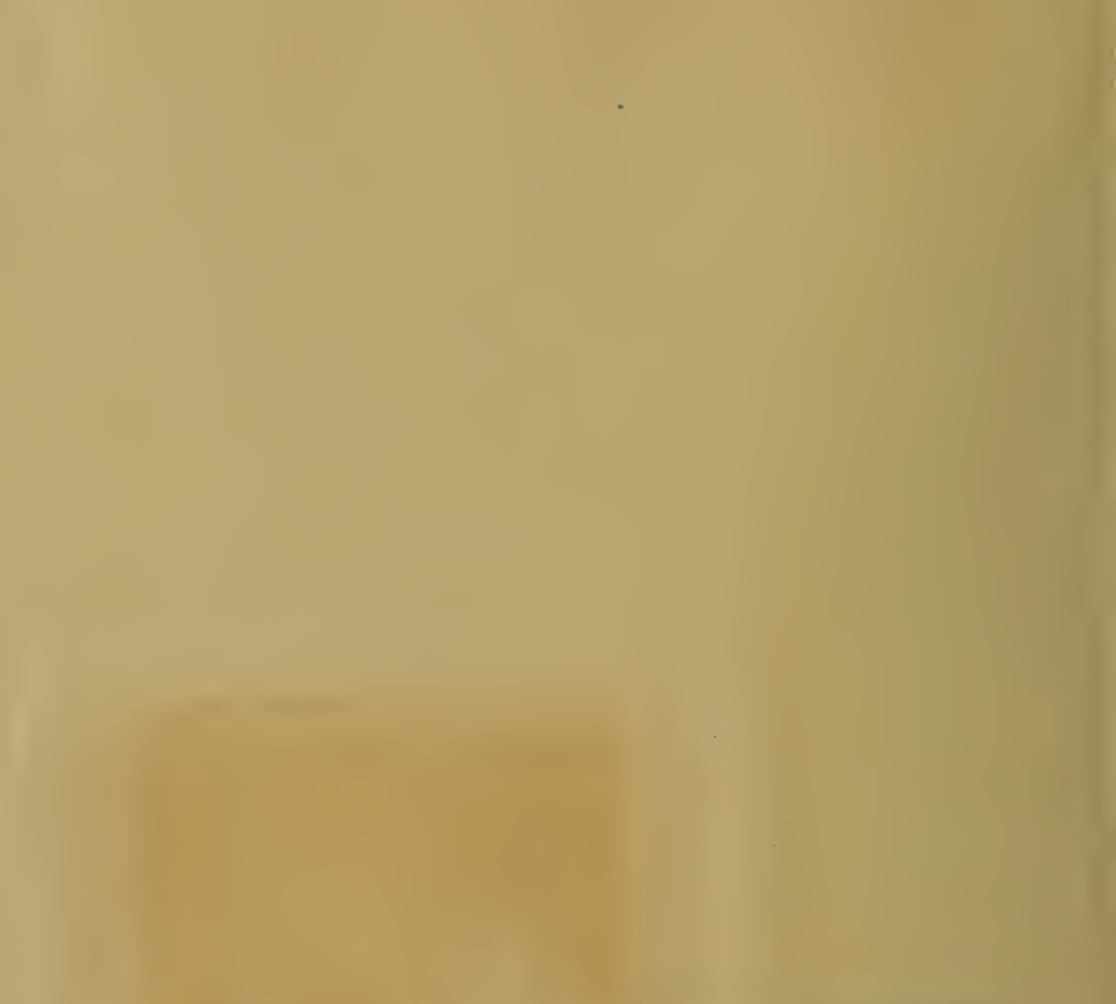

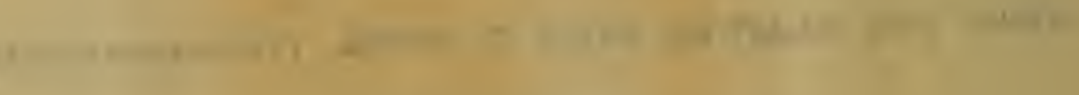

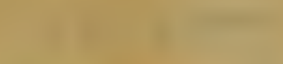

r

1

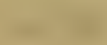

a d e

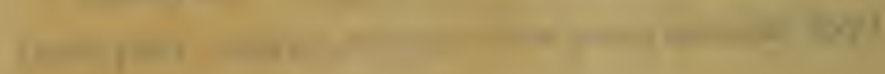




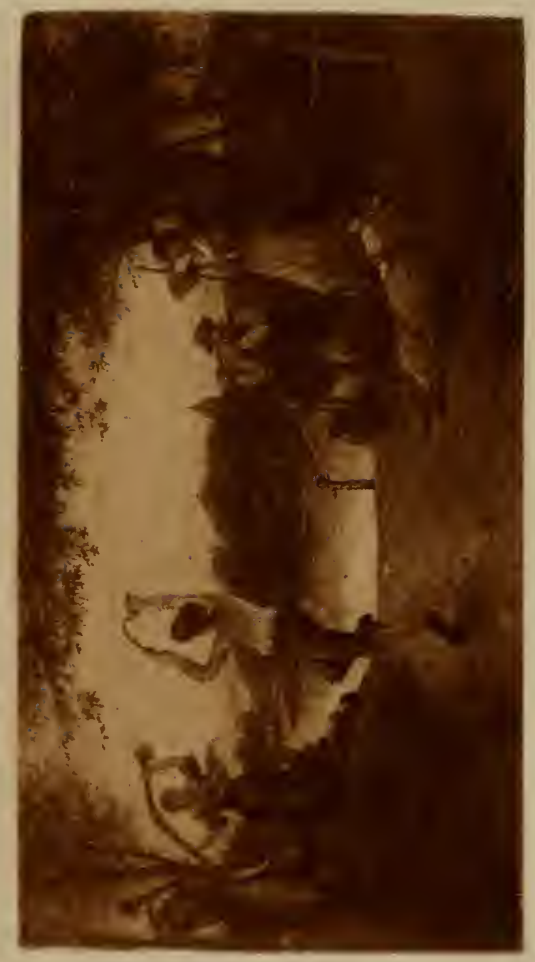



time. It is a most decorative subject, so carefully executed as to have the appearance of a finely finished drawing.

In the selection of etchings it is necessary to be mindful of the rule that the best is the cheapest, and it is only the best which will survive to be a "thing of beauty and a joy forever." If good etchings are selected for the decoration of our walls, they will, like good works in painting or any other art, never change with the fashion, and never lose any of the peculiar charms and merits which belong to good etching alone. 

THE EVENING HOUR.

an Original Etching by M. M. Taylor.

Upon Japanese paper, with remarque, signed. roo printed . . . . \$6 oo No prints.

THE SOWER.

An Original Etching by M. M. Taylor.

Upon Japanese paper, with remarque, signed. roo printed . . . \$10

OLD SWEDE'S CHURCH (GLORIA DEI), PHILADELPHIA.

Etched by L. E. Faber, from a Drawing by Prof. H. Faber.

Upon Whatman's hand made paper, with remarque, signed. 50 printed $\$ 1500$ Prints .................. 500 
